\title{
Growth promotion of Pinus radiata seedlings by soil inoculation and seed pretreatment with the biological control agent Clonostachys rosea
}

\section{Promoción de crecimiento de plántulas de Pinus radiata a través de aplicación del agente de control biológico Clonostachys rosea en suelo y pretratamiento de semillas}

\author{
Priscila Moraga-Suazo* \& Eugenio Sanfuentes \\ Plant Pathology Lab. Biotechnology Center and Faculty of Forest Sciences, Barrio Universitario s/n. University of Concepción. \\ Chile. \\ *prmoraga@udec.cl
}

\begin{abstract}
Twenty-one Clonostachys rosea strains, previously selected by its biocontrol activity higher than $80 \%$ against Fusarium circinatum, were evaluated for its ability to promote growth of Pinus radiata seedlings on natural substrate. Stem height, root length, dry weight of stem and roots, and ectomycorrhization were measured at 102 days after seeding. The results showed significant differences between some of the tested C. rosea strains when compared to the controls, showing increases for plant height of $25 \%$, dry stem mass of $37 \%$, root length of $13.5 \%$, dry root mass of $20.5 \%$ and ectomycorrhization of $55 \%$ when compared to their respective controls, demonstrating a possible dual use of these strains for both plant protection and increased biomass of $P$. radiata.
\end{abstract}

KEYWORDs: Biocontrol agents, biofertilizers, growth promoters, nurseries.

\section{RESUMEN}

Veintiún aislamientos de C. rosea, previamente seleccionadas por su actividad de biocontrol superior al $80 \%$ contra Fusarium circinatum, fueron evaluadas en su habilidad para promover el crecimiento de plántulas de Pinus radiata sobre substrato natural. Las variables altura de tallo, longitud de raíz, masa seca de tallo y raíz, y ectomicorrización fueron medidas a los 102 días posterior a la siembra. Los resultados muestran el aumento significativo de las variables evaluadas con la aplicación de algunos de los aislamientos de C. rosea, alcanzando incrementos del $25 \%$ en altura, $37 \%$ en peso seco del tallo, $13,5 \%$ en la longitud de la raíz, 20,5\% en peso seco de la raíz, y 55\% de ectomicorrización, demostrando un posible uso dual de estas cepas tanto para protección fitosanitaria como para incremento en la biomasa de $P$. radiata.

Palabras clave: Agentes de biocontrol, biofertilizantes, promotores de crecimiento, viveros.

\section{INTRODUCTION}

Clonostachys rosea (Link) Schroers, Samuels, Seifert \& W. Gams (teleomorph Bionectria ochrouleuca) is a nonpathogenic and cosmopolitan fungus with a worldwide distribution and also recognized as mycoparasite (Hoopen et al. 2003, Lübeck et al. 2002, Sutton et al. 2002). The antagonist activity of $C$. rosea is of wide spectrum, and is currently recognized as a strong biological control agent (BCA) against several pathogenic fungi (Lahoz et al. 2004, Morandi et al. 2001, Nobre et al. 2005, Rodriguez et al. 2011, Sutton et al. 2002, Tarantino et al. 2006). Studies aimed to the evaluation of $C$. rosea against important diseases in the forestry such as the gray mold caused by Botrytis cinerea Pers. on seedlings of Eucalyptus globulus Labill. (Molina et al. 2006, Zaldúa \& Sanfuentes 2010), and the damping-off caused by Fusarium circinatum Nirenberg \& O'Donnell on Pinus radiata D. Don (Moraga-Suazo et al. 2011, Moraga-Suazo et al. 2016), demonstrated a reduction on the disease by diverse mechanisms, reaching biocontrol levels higher than $80 \%$ (Valdebenito 2016).

The plant growth promotion effect has been observed on inoculated plants with $C$. rosea on different crops, including wheat, tomato, barley, rose, geranium and cucumber (Johansen et al. 2005, Ravnskov et al. 2006, Roberti et al. 2008, Sutton et al. 2008). In forest species there are few 
cases of growth promotion stimulated by microorganisms, as an example, in poplar hybrids (Populus trichocarpa $x$ Populus deltoides) growing on sandy soils, an endophytic bacterium isolated from the stems, Enterobacter sp. strain 638, increased the biomass production on cuttings in greenhouse assays (Taghavi et al. 2009).

Currently there is no information on the effect of $C$. rosea strains with biocontrol activity, on the growth promotion of forest species, therefore the aim of this study was to evaluate the effect of selected $C$. rosea strains as growth promoters in $P$. radiata seedlings.

\section{MATERIALS AND METHODS}

Plant material and $C$. Rosea Strains

Seeds from $P$. radiata originated from controlled pollinations, were provided by Forestal Mininco S.A. Twenty-one $C$. rosea strains belonging to the collection of Forest Pathology Lab at University of Concepción were included in this study (Table 1). The strains were collected mainly from root and soil of $P$. radiata plantations and selected for their activity as BCA, providing protection over $80 \%$ against $F$. circinatum under greenhouse conditions (Valdebenito 2016). C. rosea strains were stored in tubes containing Potato Dextrose Agar (PDA) as culture medium at $4{ }^{\circ} \mathrm{C}$ and replicated in Petri dishes containing PDA and growth at $25{ }^{\circ} \mathrm{C}$ for $7 \mathrm{~d}$, this inoculum was used to produce large-scale cultures of the strains by solid media cultivation according to Cavalcante et al. (2008).

\section{GROWTH PROMOTION ASSAYS}

Conidial suspension ( $1 \times 10^{7}$ conidia $\mathrm{x} \mathrm{mL}^{-1}$ in water $)$ of each C. rosea strain was applied by immersion of seeds for 30 min, $24 \mathrm{~h}$ before seeding. A second C. rosea application to the natural substrate was applied at seeding time and a third application after germination, in both cases by spraying the substrate. Non-sterilized (natural) composted pine cortex substrate was used for the assay. A commercial product (Trichonativa ${ }^{\circledR}$, Bioinsumos Nativa Ltda, Chile) based on Trichoderma spp. was used as control treatment (CT). In order to compare to the tested strains, the active ingredient concentration was adjusted to $1 \times 10^{7}$ conidia $\mathrm{x} \mathrm{mL} \mathrm{mL}^{-1}$. Sterilized distilled water was used as an absolute control treatment (AT). Eighty-four seeds for each treatment, with three replicates by treatment and twenty-three treatments were established. The experiment was carried out under operational conditions in the Carlos Douglas nursery belonging to Forestal Mininco S.A. At 102 days after seeding, forty plants were collected from the center of each tray in order to evaluate phenotypical characteristics, separating the root system from the substrate with water. A caliper was used to measure the stem height and root length. Roots and stems were then blotted dry with paper towels, separated into root and stem sections, and then dried at $105^{\circ} \mathrm{C}$ for $48 \mathrm{~h}$ in order to measure the dried weight. The percentage of ectomycorrhizal colonization was estimated by counting the number of root tips with ectomycorrhizal colonization (visualized as short roots) over the total number of root tips obtained for each seedling (Walbert et al. 2010).

\section{DATA ANALYSIS}

The experiment was arranged in a completely randomized design with twenty-three treatments. Each treatment was composed of three replicates and each replicate consisted of thirty seedlings in order to evaluate height and dry weight of stem, and length and dry weight of root. For the percentage of ectomycorrhizal colonization, the five treatments with best performance in growth promotion were selected. Each treatment was composed of three replicates and ten seedlings per replicate. Statistical data analysis was performed by ANOVA at a significance level of 0.05. All data were subjected to analysis of homogeneity of variance and normality assumptions and pooled accordingly. Multiple comparisons were made using a Tukey test. Analyses were performed with statistical analysis software SAS (SAS Institute 2000).

\section{RESULTS AND DISCUSSION}

The mean height for absolute control treatment (AT) was $6.8 \mathrm{~cm}$, eight treatments (T1, T2, T3, T11, T12, T15, T16 and T17) showed mean heights significantly higher than AT, with T16 presenting the highest height of $8.5 \mathrm{~cm}$, an increment of $25 \%$ when compared to AT and also higher than commercial treatment $(\mathrm{CT}=7.2 \mathrm{~cm}$, Fig. 1A). About stem biomass, nine treatments (T1, T2, T3, T5, T9, T11, T12, T15 and T16) showed differences when compared to AT, with $\mathrm{T} 1$ presenting the highest value of $0.26 \mathrm{~g}$, representing an increment of $37 \%$ in biomass when was compared with AT $(0.19 \mathrm{~g})$. CT $(0.20 \mathrm{~g})$ was not different to AT (Fig. 1B).

Five strains (T7, T12, T13, T14 and T17) increased length of roots when compared to AT (Fig. 2A), T14 presented the highest value of $12 \mathrm{~cm}$, which increased $13.5 \%$ with respect to AT $(10.6 \mathrm{~cm})$. No significant differences were found between AT and CT treatments. For root dry weight, four treatments (T1, T8, T12 and T16) presented significant differences with AT, the highest value for root dry biomass was obtained by T12 (0.182 g), representing an increment of $20.5 \%$ higher than AT $(0.151 \mathrm{~g})$. For root biomass CT control was not significantly different to AT (Fig. 2B).

As indicated on Figure 3, T2 (45\%) and T3 (51\%) treatments showed percentages of ectomycorrhizal colonization higher than AT (32.9\%), showing potential for increasing plant productivity and root quality by the use of selected $C$. rosea strains, which will allow a better performance of the antagonist-treated plants from nurseries to their final plantation field. 
Sutton et al. (2008) reported that the application of Pg 88-710 strain of C. rosea increased growth and production of roses, geraniums and cucumbers. The same beneficial effect was found by Ravnskov et al. (2006) in tomato plants, showing an increase in the content of phosphorus and a reduction of nitrogen content in leaves after antagonist application. Application of antagonists also increased the weight of plants 30 days after sowing (Macedo 2011). In our study, several strains were able to promote growth, significantly increasing stem height (25\%), stem dry weight (37\%), root length (13.5\%), root dry weight $(20.5 \%)$ and ectomycorrhizal colonization (55\%). Even when several strains do not increase the growth, none of the isolates showed a deleterious effect on plants.

BCAs may have an important role on plant growth promotion, but the information for forest species is still scarce. Donoso et al. (2008) demonstrated the effect of Trichoderma harzianum Rifai applied on pine cortex substrate in the growth promotion of $P$. radiata, increasing the height, total biomass and aerial biomass of treated plants. In the same pine species, the application of T. harzianum along with ectomycorrhizal fungi Suillus luteus (L.) Roussel and Rhizopogon luteolus Fr. stimulated plant growth (Chavez et al. 2014). Nevertheless, to date the few studies of strains of $C$. rosea on forest species were focused on the biocontrol effect against the pathogens Botrytis cinerea (Zaldúa \& Sanfuentes 2010) and F. circinatum (Moraga-Suazo et al. 2011, Valdebenito 2016, Moraga-Suazo et al. 2016). Even when the biocontrol effect was successful, there is a lack of information about the potential growth effect of these BCAs over forest nurseries.

TABLE 1. Information of each treatment employed in this study. / Información de cada tratamiento empleado en este estudio.

\begin{tabular}{|c|c|c|c|}
\hline Treatment & Place Name & SpeCIES & Tissue/soIL \\
\hline T00 & \multicolumn{3}{|c|}{ Absolut treatment: water } \\
\hline T01 & Carlos Douglas & Pinus radiata & Soil \\
\hline T02 & Los Castaños & Pinus radiata & Root \\
\hline T03 & Quivolgo & Pinus radiata & Soil \\
\hline T04 & La Posada & Pinus radiata & Soil \\
\hline T05 & Quivolgo & Pinus radiata & Shoot \\
\hline T06 & La Posada & Pinus radiata & Root \\
\hline T07 & Fundo El Sauce & Agronomic Crop & Soil \\
\hline T08 & San Isidro & Pinus radiata & Root \\
\hline T09 & La Posada & Pinus radiata & Soil \\
\hline $\mathrm{T} 10$ & Quillón & Vineyard & Soil \\
\hline $\mathrm{T} 11$ & Los Castaños & Pinus radiata & Root \\
\hline T12 & La Posada & Pinus radiata & Root \\
\hline $\mathrm{T} 13$ & Ruta Itata & Populus sp. & Soil \\
\hline T14 & Coyanmahuida & Native Forest & Soil \\
\hline $\mathrm{T} 15$ & Santa Juana & Agronomic Crop & Soil \\
\hline T16 & San Isidro & Pinus radiata & Root \\
\hline $\mathrm{T} 17$ & La Quila & Pinus radiata & Soil \\
\hline $\mathrm{T} 18$ & Coyanmahuida & Non identified & Shoot \\
\hline T19 & Quivolgo & Pinus radiata & Soil \\
\hline $\mathrm{T} 20$ & Parral & Agronomic Crop & Soil \\
\hline $\mathrm{T} 21$ & Quillón & Maytenus boaria & Shoot \\
\hline $\mathrm{T} 22$ & Control treatment: & $\begin{array}{l}\text { ial product (Tricho } \\
\text { T. parceramosum) }\end{array}$ & rzianum, 1 \\
\hline
\end{tabular}


Correa et al. (2010) studied the C. rosea performance applied to lettuce in a hydroponic cultivation system and observed that $C$. rosea was able to reduce the incidence of root rot caused by Pythium aphanidermatum (Edson) Fitzp., nevertheless in this case the antagonist failed to promote plant growth, indicating that the interaction between antagonists (strains) and host could be specific for each case (Moreira et al. 2014). This results indicate that not always an antagonistic strain has both good biological control and growth promoting activity, showing the requirement to study both characteristics for each selected strain.

The present study was conducted in natural substrate, indicating that the seedlings response to the evaluated $C$. rosea strains corresponds to a direct interaction of the $C$. rosea strains with the host tissues, rather than an indirect interaction of pathogen suppression. It is worth to note that the strains employed in this study were mainly isolated from $P$. radiata soil and roots, this could be a key factor in the success performance of some strains because a better adaptation to the introduced environment and microbial competition. It is not clear what is the effect of $C$. rosea with the microorganisms present in the rhizosphere, or with the ectomycorrhizal species associated with $P$. radiata. There are three possible outcomes between mycorrhizal fungi and BCA or growth promoters: synergy (Fracchia et al. 2003, Martinez et al. 2004), antagonism (Ravnskov et al. 2006) and neutrality (Mar Vasquez et al. 2000, Siddiqui and Akhtar 2009). In the case of the recognized BCA T. harzianum, also mentioned as a growth promoter, different effects on mycorrhizal fungi have been found, being synergistic to Glomus intraradices N.C. Schenk \& G.S. Sm. in melon plants (Martinez-Medina et al. 2010), neutral to G. deserticola Trappe, Bloss \& J.A. Menge in maize plants (Mar Vasquez et al. 2000), and antagonistic for G. intraradices in cucumber plants (Green et al. 1999). In the present study, a synergistic effect generated by the T2 and $\mathrm{T} 3$ was observed, while the other treatments (T1, T12, T16, T17) generated a neutral effect. This contrasts with a previous study where an antagonist effect between $C$. rosea and G. intraradices was observed (Ravnskov et al. 2006). According to these records it is possible to indicate that the effect of $C$. rosea on roots of the host seems to be dependent on the particular strain tested.
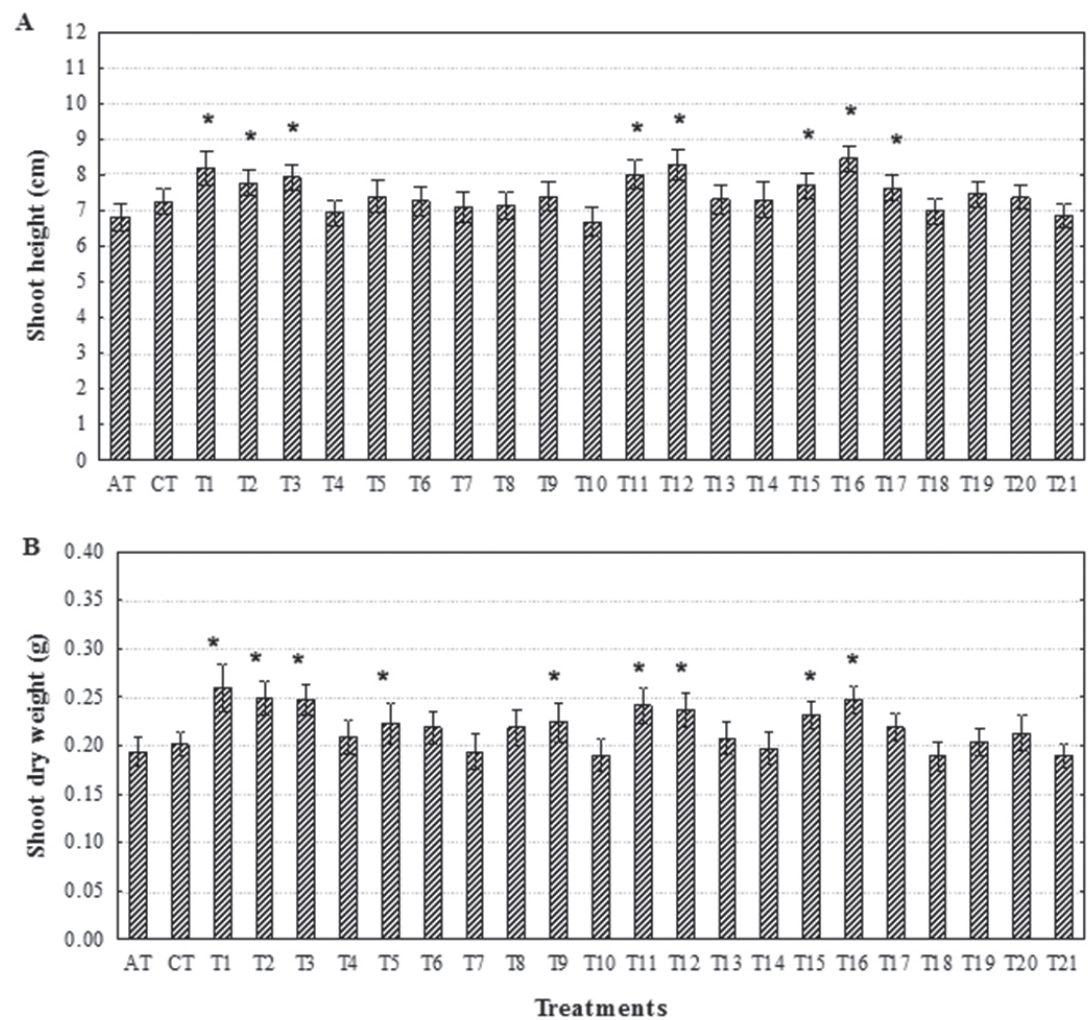

FiguRE 1. Effect of Clonostachys rosea applied as seed pretreatment and soil on height and dry weight of shoots. Asterisks indicate treatments with means significantly higher than absolute control treatment (AT) $(\mathrm{p}=0.05$ Tukey test). Vertical bars correspond to standard error, $\mathrm{n}=30$ plants per treatment. A, Mean height $(\mathrm{cm})$ per treatment. B, Mean dry weight $(\mathrm{g})$ per treatment. / Efecto de la aplicación de Clonostachys rosea como pretratamiento de semillas y suelo sobre la altura y peso seco de brotes. Asteriscos indican tratamientos con medias significativamente más altas que el control absoluto $(\mathrm{p}=0.05$, test de Tukey). Barra vertical corresponde a error estándar, $\mathrm{n}=30$ plantas por tratamiento, 3 repeticiones. A: Altura media $(\mathrm{cm})$ por tratamiento. B: Peso seco promedio $(\mathrm{g})$ por tratamiento. 
Based on these results, it is clear that the strains with both increased growth promotion of $P$. radiata and improvement effect on their root quality, have potential as inoculants on the forest industry. All $C$. rosea strains tested here were selected due to their biocontrol capacity against
F. circinatum higher than $80 \%$ on operational conditions on nurseries of $P$. radiata, and will be included for the future formulation of biological products aimed at the improvement of the sanitary status (control of $F$. circinatum) and the increase of the yields of $P$. radiata.
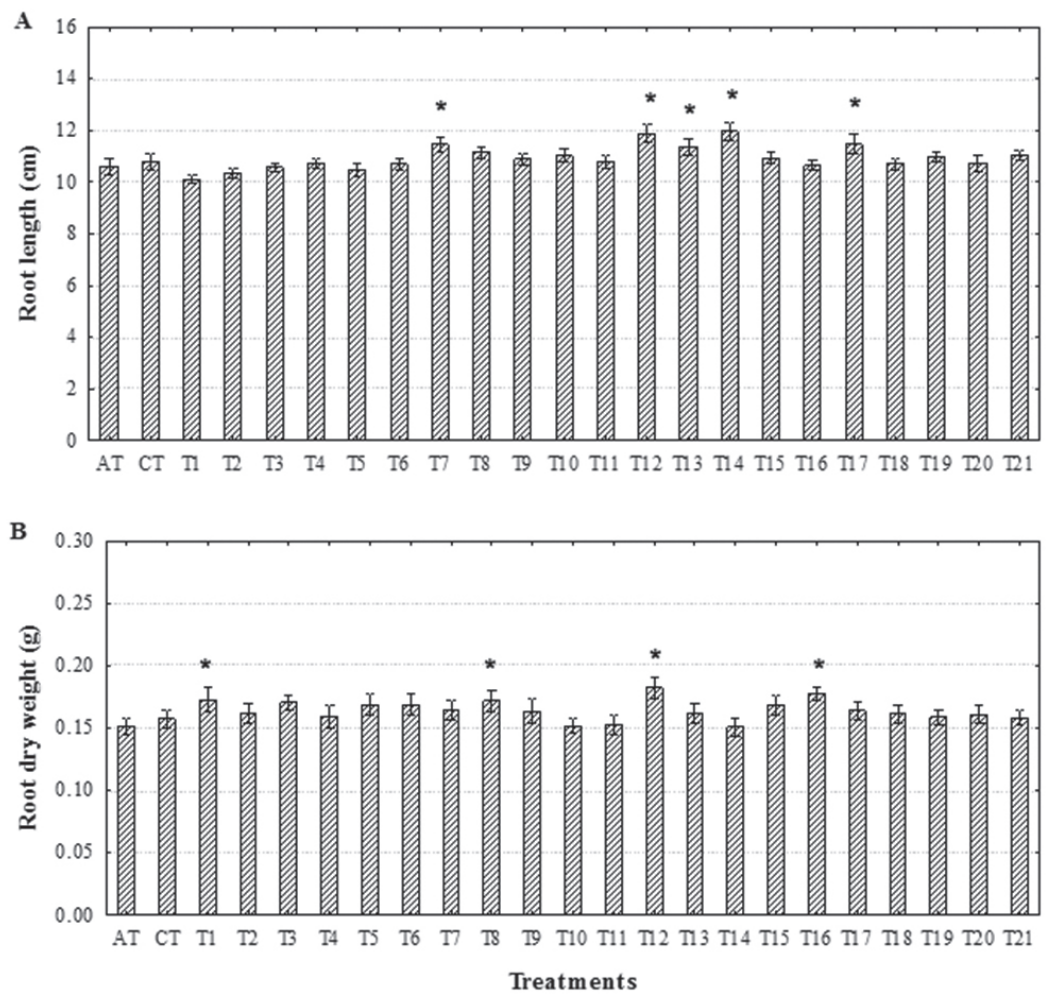

FIGURE 2. Effect of Clonostachys rosea applied as seed pretreatment and soil on length and dry weight of roots. Asterisks indicate treatments with means significantly higher than absolute control treatment (AT) ( $\mathrm{p}=0.05$ Tukey test). Vertical bars corresponds to standard error, $\mathrm{n}$ $=30$ plants per treatment. A, Mean length $(\mathrm{cm})$ per treatment. B, Mean dry weights $(\mathrm{g})$ per treatment. / Efecto de Clonostachys rosea aplicado como pretratamiento de semillas y suelo sobre la longitud y peso seco de raíces. Asteriscos indican tratamientos con medias significativamente más altas que el control absoluto ( $\mathrm{p}=0.05$, test de Tukey). Barra vertical corresponde a error estándar, $\mathrm{n}=30 \mathrm{plantas}$ por tratamiento, 3 repeticiones. A: Longitud media $(\mathrm{cm})$ por tratamiento. B: Peso seco promedio $(\mathrm{g})$ por tratamiento.

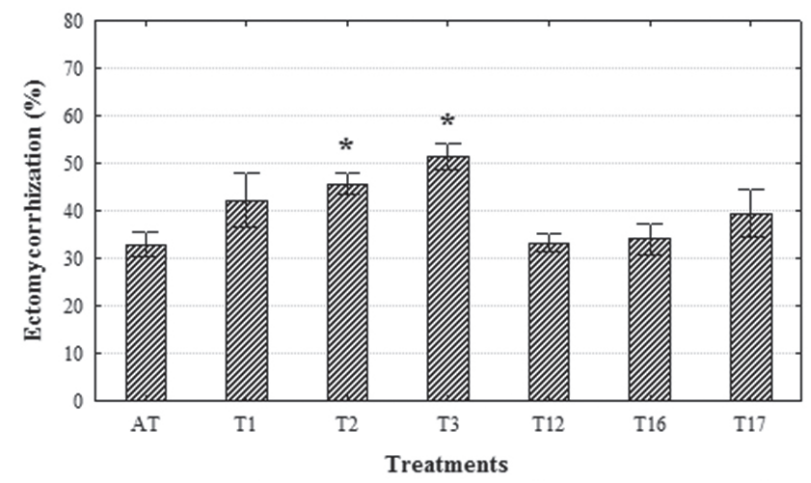

FIgURE 3. Effect of Clonostachys rosea applied as seed pretreatment and soil inoculation on percentage of ectomycorrhization. Asterisks indicate treatments with means significantly higher than absolute control treatment (AT) ( $\mathrm{p}=0.05$ Tukey test). Vertical bar correspond to standard error, $\mathrm{n}=10$ seedlings per treatment, 3 replicates. / Efecto de Clonostachys rosea aplicado como pretratamiento de semillas y suelo sobre el porcentaje de ectomicorrización. Asteriscos indican tratamientos con media significativamente mayor que el control absoluto (AT) $(\mathrm{p}=0.05$, test de Tukey). Barra vertical corresponde a error estándar, $\mathrm{n}=10$ plantas por tratamiento, 3 réplicas. 


\section{CONCLUSION}

C. rosea strains enhance the health of $P$. radiata seedlings and increase their growth, along with an improvement of root quality increasing the percentage of ectomycorrhized roots.

\section{ACKNOWLEDGEMENTS}

The authors acknowledge Mr Francisco Rodríguez for provide plant material and facilities on Forestal Mininco S.A. This work was funded by Postdoctoral Fellowship FONDECYT No 3130606

\section{REFERENCES}

Cavalcante, R., Lima, H., Pinto, G., Gava, C., Rodrigues, S. 2008. Effect of moisture on Trichoderma conidia production on corn and wheat bran by solid-state fermentation. Food and Bioprocess Technology 1: 100-104.

Chavez, D., Pereira, G., Machuca, A. 2014. Estimulación del crecimiento en plántulas de Pinus radiata utilizando hongos ectomicorrícicos y saprobios como biofertilizantes. Bosque 35(1): 57-63.

Correa, E.B., Bettiol, W., Morandi, M. 2010. Biological control of Pythium aphanidermatum root rot and growth promotion of hydroponic lettuce by Clonostachys rosea. Tropical Plant Pathology 35: 248-252.

Donoso, E., Lobos, G., Rojas, N. 2008. Efecto de Trichoderma harzianum y compost sobre el crecimiento de plántulas de Pinus radiata en vivero. Bosque 29(1): 52-57.

Fracchia, S., Godeas, A., Scervino, J.M., Sampedro, I., Ocampo, J.A., García-Romera, I. 2003. Interaction between the soil yeast Rhodotorula mucilaginosa and the arbuscular mycorrhizal fungi Glomus mosseae and Gigaspora rosea. Soil Biology and Biochemistry 35: 701-707.

Green, H., Larsen, J., Olson P., Jensen D.F., Jakobsen, I. 1999. Suppression of the Biocontrol Agent Trichoderma harzianum by Mycelium of the Arbuscular Mycorrhizal Fungus Glomus intraradices in Root-Free Soil. Applied and Environmental Microbiology 65(4):1428-1434.

Hoopen, G.M., Rees, R., Aisa, P., Stirrup, T., Krauss, U. 2003. Population dynamics of epiphytic mycoparasites of the genera Clonostachys and Fusarium for the biocontrol of black pod (Phytophthora palmivora) and moniliasis (Moniliophthora roreri) on cocoa (Theobroma cacao). Mycological Research 107(5): 587-596.

Johansen, A., Knudsen, I., Binnerup, S., Winding, A., Johansen, J., Jensen, L., Andersen, K., Svenning M., Bonde, T. 2005. Non-target effects of the microbial control agents Pseudomonas fluorescens DR54 and Clonostachys rosea IK726 in soils cropped with barley followed by sugar beet: a greenhouse assessment. Soil Biology and Biochemistry 37: 2225-2239.

Lahoz, E., Contillo, R. Porrone, F. 2004. Induction of systemic resistance of Erysiphe orontii Cast in tobacco by application on roots of an isolate of Gliocladium roseum
Bainier. Journal of Phytopathology 152: 465-470.

Lübeck, M., Knudsen, I.M.B., Jensen, B., Thrane, U., Janvier, C., JENSEN, D.F. 2002. GUS and GFP transformation of the biocontrol strain Clonostachys rosea IK726 and the use of these marker genes in ecological studies. Mycological Research 106(7): 815-826.

Macedo, P.E.F. 2011. Promoção de crescimento de plantas mediada por Clonostachys rosea. Dissertação de Mestrado, Universidade Federal de Viçosa. Viçosa, MG. 36 pp.

MarVázquez, M., César, S., Azcón, R., Barea, J.M. 2000. Interactions between arbuscular mycorrhizal fungi and other microbial inoculants (Azospirillum, Pseudomonas, Trichoderma) and their effects on microbial population and enzyme activities in the rhizosphere of maize plants. Applied Soil Ecology 15: 261-272.

Martinez, A., Obertello, M., Pardo, A., Ocampo, J.A., Godeas, A. 2004. Interactions between Trichoderma pseudokoningii strains and the arbuscular mycorrhizal fungi Glomus mosseae and Gigaspora rosea. Mycorrhiza 14: 79-84.

Martínez-Medina, A., Pascual, J.A., Pérez-Alfocea, F., Albacete, A., Roldán, A. 2010. Trichoderma harzianum and Glomus intraradices modify the hormone disruption induced by Fusarium oxysporum infection in melon plants. Phytopathology 100: 682-688.

Molina, G., Zaldúa, S., Gonzalez, G., Sanfuentes, E. 2006. Selección de hongos antagonistas para el control biológico de Botrytis cinerea en viveros forestales. Bosque 27(2): 126-134.

Moraga-Suazo, P., Le-Feuvre, R., Sanfuentes, E. 2016. Induced systemic resistance triggered by Clonostachys rosea against Fusarium circinatum in Pinus radiata. Forest Research 5: 174.

Moraga-Suazo, P., Opazo, A., Zaldúa, S., Gonzalez, G., SANFUENTES, E. 2011. Evaluation of Trichoderma spp. and Clonostachys spp. strains to control Fusarium circinatum in Pinus radiata seedlings. Chilean Journal of Agricultural Research 71: 412-417.

Morand, M.A.B., Maffia, L.A., Sutton, J.C. 2001. Development of Clonostachys rosea and interactions with Botrytis cinerea in rose leaves and residues. Phytoparasitica 29(2): 103-113.

Moreira, R., Franca, P., Borges, A., Maffia, L. 2014. Uso e perspectiva de Clonostachys rosea como agente de biocontrole. Revista de Ciencias Agrícolas 31(1): 78-91.

Nobre, S.A.M., Maffia, L., Mizubuti, E., Cota, L.V., Dias, A.P.S. 2005. Selection of Clonostachys rosea isolates from Brazilian ecosystem effective in controlling Botrytis cinerea. Biological Control 34: 132-143.

Ravnskov, S., Jensen, B., Knudsen, I.M.B., Bodker, L., Jensen, D.F., Karlinski, L., Larsen, J. 2006. Soil inoculation with the biocontrol agent Clonostachys rosea and the mycorrhizal fungus Glomus intraradices results in mutual inhibition, plant growth promotion and alteration of soil microbial communities. Soil Biology and Biochemistry 38: 3453-3462

Roberti, R., Veronesi, A.R., Cesari, A., Cascone, A., Bernardino, I.D., Bertini, L., CARUso, C. 2008. Induction of PR proteins and resistance by the biocontrol agent Clonostachys rosea in wheat plants infected with Fusarium culmorum. Plant Science 175: 339-347. 
Rodriguez, M.A., Cabrera, G., Gozzo, F.C., Eberlin, M.N., Godeas, A. 2011. Clonostachys rosea BAFC3874 as a Sclerotinia sclerotiorum antagonist: mechanism involved and potential as a biocontrol agent. Journal of Applied Microbiology 110: 1177-1186.

Siddiqui, Z.A., AkHTAR, M.S. 2009. Effects of antagonistic fungi, plant growth promoting rhizobacteria, and arbuscular mycorrhizal fungi alone and in combination on the reproduction of Meloidogyne incognita and growth of tomato. Journal of General Plant Pathology 75: 144-153.

Sutton, J.C., Liu, W., HuAng, R., Owen-Going, N. 2002. Ability of Clonostachys rosea to establish and suppress sporulation potential of Botrytis cinerea in deleafed stems of hydroponic greenhouse tomatoes. Biocontrol Science and Technology 12: 413-425.

Sutton, J.C., Liu, W., Ma, J., Brown, W.G., Stewart, J.F., WaLKer, G.D. 2008. Evaluation of the fungal endophyte Clonostachys rosea as an inoculant to enhance growth, fitness and productivity of crops plants. Acta Horticulturae 782: 279-286.

Taghavi, S., Garafola, C., Monchy, S., Newman, L., Hoffman, A., Weyens, N., Barac, T., Vangronsveld, J., Van der
Lelie, D. 2009. Genome survey and characterization of endophytic bacteria exhibiting a beneficial effect on growth and development Poplar trees. Applied and Environmental Microbiology 75(3): 748-757.

Tarantino, P., Caiazzo, R., Carella, A., Lahoz, E. 2006. Control of Rhizoctonia solani in a tobacco-float system using low rates of iprodione- and iprodione-resistant strains of Gliocladium roseum. Crop Protection 26: 1298-1302.

Valdebenito, D. 2016. Desarrollo de formulaciones biológicas a base de cepas de Trichoderma spp. y Clonostachys spp. para el control de Fusarium circinatum en plántulas de Pinus radiata. Tesis para optar al grado de Doctor en Ciencias Forestales. Facultad de Ciencias Forestales, Universidad de Concepción, Chile. 90 pp.

Walbert, K., Ramsfield, T., Ridgway, H., \& Jones, E. 2010. Ectomycorrhizal species associated with Pinus radiata in New Zealand including novel associations determined by molecular analysis. Mycorrhiza 20: 209-215.

ZaldúA, S., SAnfuentes, E. 2010. Botrytis cinerea control in Eucalyptus globulus mini-cuttings using Clonostachys and Trichoderma strains. Chilean Journal of Agricultural Research 70(4): 576-582.

Recibido: 24.05.2016

Aceptado: 13.03.2017 